\title{
Analysis of Figurative Language and Imagery in Taylor Swift's Songs
}

\author{
Sari Rishita Siallagan ${ }^{1}$, Sulastri Manurung ${ }^{2}$, Juwita Boneka Sinaga ${ }^{3}$ \\ English Education Department \\ University of Riau Kepulauan \\ saririshita@gmai.com¹, lastri.manru@yahoo.com², juwitaboneka@gmail.com ${ }^{3}$
}

\begin{abstract}
The aim of this research is to find out the kinds of figurative language and imagery in the song lyrics of Taylor Swift's "1989” Album. Furthermore, in this research the researcher used qualitative descriptive method. The result of the study is presented in the form of paragraphs. The researcher analyzed the songs by reading them intensively and giving attention for each line. After that, the researcher examined the figurative language and imagery of the songs lyrics. After investigating the sentence in the songs lyrics, the researcher found eight kinds of figurative languages that are used in the songs lyrics, they are personification, metaphor, hyperbole, simile, oxymoron, allusion, litotes and metonymy. Six kinds of imagery also used in the songs lyrics, they are visual imagery, auditory imagery, organic imagery, kinesthetic imagery, tactile imagery and olfactory imagery. The most dominant of figurative language used is personification and the dominant imagery used is visual imagery.
\end{abstract}

Keywords: figurative language, imagery, lyrics

\section{INTRODUCTION}

Literature is influential to human's life. It is one way to express feeling, thought, emotion, and experience. Literature born due to the basic human urge to express himself, showed an interest in the mankind problem, and showed an interest in reality which lasts all the time (Semi, 2012:1). Three major literary genres are fiction, drama, and poetry (Klarer, 1999:9). Poetry influenced by many factors which assist the poetry in order to become more meaningful and interesting to be heard and read. Those factors which involved in poetry are figurative languages, symbols, imagery, senses, and rhyme.

Song is a part of literature. It is a way of life for human. If an important occasion is a meal, songs are its spices - leaving the meal incomplete without them (Dudrah, 2008:149). In a song, we can find lyrics which complete and beautify the song and makes the hearer more interested in hearing it.

Some lyrics composed in poetical composition which makes it similar with poetries that there are many words written using figurative languages. Figurative language is language 
than cannot be taken literally (or should not be taken literally only). It uses words or expressions with a meaning that is different from the literal interpretation (Arp, 2011:73). Many authors use this kind of language style to transferring their impression about something in their literary works to give special effects and unique understanding in every sentence of their works.

In poetry, the image or picture is a representation of words or something that the writer feels. An image will do more than just state that we can see, hear, feel, smell, or taste something (Grover, 1994:25). According to Abrams in his book A Glossary of Literary Terms seventh edition (1999:121) imagery is used to signify all the objects and qualities of sense perception referred to in a poem or other work of literature. Based on the reasons above, it is important to analyze the used of figurative language and imagery in song lyrics. That is why the researcher needs to analyze imagery and figurative language more deeply.

This study was focused in analyzing the kinds of imagery and figurative language that occur in Taylor Swift's song lyrics of “1989” album. This album consists of thirteen songs. Taylor Swift was born on December 13, 1989. She is a ten-time Grammy winner, the youngest recipient in history of the music industry's highest honor, the Grammy Award for Album of the Year and she is the only female in the history of The Grammy's to win Album of the Year, twice. The researcher chose this album because there are so many figurative language and imagery found in the song lyrics of this album. The objective of the study is to answer all questions as mention in the problem of the study:

1. To identify the kinds of figurative language and imagery used in Taylor Swift's songs in “1989” Album.

2. To analyze the meaning of each kind of figurative language and imagery found in the songs lyrics.

Figurative language is language than cannot be taken literally (or should not be taken literally only). It uses words or expressions with a meaning that is different from the literal interpretation (Arp, 2011:73). Figurative language often found in literary works, such as: articles in newspaper, advertisements, novels, poems, etc.

\section{Kinds of figurative language are:}

\section{Allegory}

According to Abrams in his book A Glossary of Literary Terms Seventh Edition, Allegory is a narrative, whether in prose or verse, in which the agents and actions, and 
sometimes the setting as well, are contrived by the author to make coherent sense on the "literal," or primary, level of signification, and at the same time to signify a second, correlated order of signification.

\section{Allusion}

Thomas R Arp describes the Allusion as-a reference to something in history or previous literature-is like a richly connotative word or a symbol, a mean of suggesting far more than it says.

From the definitions above, the researcher can conclude that Allusion refers to an explicit or implicit reference to well-known events, characters, or places, mythology or literature.

\section{Hyperbole or overstatement}

Thomas R Arp defines Hyperbole or Overstatement as "simply exaggeration, but exaggeration in the service of truth.” In hyperbole, the speakers do not expect to be taken literally but they are only adding emphasis to what they really mean or in the words, they are overstating their statement.

\section{Irony}

According to Abrams, Irony is the root sense of dissembling or hiding what is actually the case; not, however, in order to deceive, but to achieve special rhetorical or artistic effects.

\section{Litotes or Understatement}

Litotes is opposite from hyperbole. It is kind of understatement where the speaker uses negative of a word ironically, to mean the opposite. According to Thomas R Arp, litotes is saying less than one means, may exist in what one says or merely in how one says it.

\section{Synecdoche}

In synecdoche a part of something is used to signify the whole, or (more rarely) the whole is used to signify a part. We use the term "ten hands" for ten workmen, or "a hundred sails" for ships and, in current slang, "wheels" to stand for an automobile (Abrams, 1999:98). 


\section{Simile}

Simile refers to an "indirect" comparison between two different things using the word "like" or "as" or an equivalent term (Mezo, 1999:1). The simile is signified by the words like: as, so, appear, more then.

\section{Metaphor}

According to Thomas R Arp added, metaphor is a figure of speech in which a comparison is made between two things essentially unlike. In first form of metaphor, as in simile, both the literal and figurative terms are named. Metaphor only makes sense when the similarities between the two things become apparent or someone understands the connection.

\section{Personification}

Personification consists of giving the attributes of a human being to an animal, an object, or a concept. It is a really subtype of metaphor, an implied comparison in which the figurative term of the comparison is always a human being (Arp, 2011:76).

\section{Metonymy}

According to Arp (2011:80), metonymy is the use of something closely related for the thing actually meant. It is figure of speech which the name of one object is replaced by another which is closely associated with it.

\section{Symbol}

Arp says that "a symbol may be roughly defined as something that means more than what it is". It is closely connected with denotation and connotation meaning. Symbol is the part of poem's structure that could not be paid attention that is caused of its function in understanding the poem meaning. A symbol can be defined simply as any object or action that means more than itself.

\section{Paradox}

According to Arp, a paradox is an apparent contradiction that is nevertheless somehow true. It often contains two statements that are both true, but in general, cannot both be true at the same time. 


\section{Oxymoron}

If the paradoxical utterance conjoins two terms that in ordinary usage are contraries it is called an oxymoron.

Imagery can be defined as the representation through language of sense experience (Arp, 2011:58). Poetry appeals directly to our sense, and through its music, rhythm, which actually hear when it read loudly. But indirectly it appeals to our sense through imagery, the representation to the imagination of sense experience. Thomas R. Arp and Greg Johnson in Perrine's Sound and Sense: An Introduction to Poetry Thirteenth Edition classifies imagery into seven types:

\section{Visual Imagery}

Visual Imagery evokes a picture of something that occurs most frequently in poetry, sometime seen in the mind eye which called by sight effect.

\section{Auditory Imagery}

Auditory imagery represents a sound like words "buzzing, tinkling, chimming” and others related to the sound. The auditory imagery is not like auditory perception. It means, when the reader reads it, he only fell the sense of hearing but not really hearing in purpose.

\section{Olfactory Imagery}

Olfactory imagery calls up the sense of smell to the reader like fragrant, unpleasant smell and the others related the aroma.

\section{Gustatory Imagery}

Gustatory imagery is an imagery which relates to the taste such as sweet and others related to the flavor.

\section{Tactile Imagery}

This imagery relates to tactile sense such as hardness, softness, wetness or heat and cold. 


\section{Organic Imagery}

Organic imagery is an imagery which related to internal sensation such as hunger, thirst, fatigue, or nausea.

\section{Kinesthetic Imagery}

Kinesthetic imagery conveys a sense of movement or tension in the muscles or joints.

\section{METHODOLOGY}

In this research, the researcher used a descriptive qualitative method, in which the data are described systematically to get an accurate and factual result. Qualitative research is a means for exploring and understanding the meaning individuals or groups ascribe to a social or human problem (Creswell, 2009:22). This research carried out by formulating problem, collecting data, classifying data and analyzing data.

The source of the data was taken from song lyrics of 1989 album sung by Taylor Swift which consist of thirteen songs. This album is her 5th album. The researcher used documentation method as the way to collect the data because the researcher collected the data from songs. According to Arikunto (2006:321), study document is getting the data about case or variable as note, transcripts, book, magazine, etc. The data are collected by using the following steps:

a. Reads all the songs lyrics from 1989 Album by Taylor Swift

b. Selects figurative language and imagery belonging to Taylor Swift's song lyrics in “1989” album

In analyzing the data, the researcher used theory qualitative researcher which goes through a series of steps and iterations: gathering data, examining data, comparing prior data to newer data and developing new data to gather. In reference with theory above, the procedure of analyzing data are as follows:

a. Read and learn all sentences from the lyrics of the songs.

b. Identify the figurative language and imagery

c. Identify the contextual meaning of those figurative languages

d. Analyze and classify the sentences which had figurative language and imagery or in terms of their structural aspect. 


\section{RESULTS}

\section{Welcome to New York}

\section{Figurative language analysis}

The village is a glow (line 2; Metaphor)

From the above phrases, the lyricist uses metaphor in comparing two things: the village and glow. These phrases described about New York as a village which is shiny among others.

\section{Imagery analysis}

The village is a glow (line 2; Visual Imagery)

In the quotation above, it is clear the imagery which related to sense of sight. Through that word, the listener is invited to imagine about what the song is expressed. The word "glow" in the phrase is to state that New York stand out among others.

\section{Blank Space}

\section{Figurative language analysis}

Look at that face, you look like my next mistake (line 6; Simile)

In this lyric, the lyricist uses simile to compare the face of the man with mistakes that she did with her ex-lover. This explains how all her relationship ended.

\section{Imagery analysis}

If the high was worth the pain (line 19; Organic Imagery)

The listener invited to feels the lyricist's feeling in her relationship. The word "pain” is describing the bad end of her relationship.

\section{Style}

\section{Figurative language analysis}

Midnight, you come and pick me up (line 1; Personification) 
On the lyrics, the lyricist gives attribute of human being to the time as if it is human that could come and picked her up.

\section{Imagery analysis}

Long drive, could end in burning flames or paradise (line 3; Visual Imagery)

Through this lyric, the listener invited to imagine of what the lyricist is expressed. It is the journey of her relationship. It could end in burning flames or paradise which means her relationship could be ruin or lasting. It is so clear that the word is the imagery which related to visual seeing.

\section{Out of the Woods}

\section{Figurative language analysis}

The rest of the world was black and white (line 7; Oxymoron)

It is a contrary utterance which is conjoin word "black" and "white". This line consider as oxymoron because black and white are opposites in color and they are put together in same verse.

\section{Imagery analysis}

The rest of the world was black and white (line 7; Visual Imagery)

This line contains visual imagery because this line brings the listeners to see the image of the world with black and white color. The lyricist describes that she and her lover stand out among others.

\section{All You Had to Do was Stay}

\section{Figurative language analysis}

Had me in the palm of your hand (line 7; Hyperbole)

From the above lyric, the lyricist is exaggerating because it is not possible to have human in the palm of hand. She interprets it by saying that her boyfriend should never let her go and stay with her. 


\section{Shake it Off}

\section{Figurative language analysis}

It's like I got this music. In my mind, saying it's gonna be alright (line 11-12; Personification)

The lyricist gives an attribute of human being to the music. The line that contains personification is represented by the phrase "saying it's gonna be alright”. On the lyrics, the lyricist gives attribute of human being to the music as if it is human that could talk.

\section{Imagery analysis \\ I never miss a beat (line 21; Auditory Imagery)}

The word above showed imagery of hearing or auditory imagery. The listener felt invited to listen the tone in song. This line describes that she is perfect and never make mistakes.

\section{Wish You Would}

\section{Figurative language analysis}

We're a crooked love in a straight line down (line 13; Metaphor)

From the above phrases, the lyricist is comparing themselves to crooked love in a straight line down. She describes that they are strange lovers and has so many problems in their relationship.

\section{Imagery analysis}

Windows down, you pass my street, the memories start (line 2; Visual Imagery)

The lines above make the listener imagine and experience what the song described. It is the view when the windows down and the lyricist's boyfriend pass the street. This occasion brings memories between her and her ex-lover.

\section{Wildest Dreams}

Figurative language analysis

I thought heaven can't help me now (line 3; Personification) 
Whenever an inanimate object or abstraction is given human qualities or abilities, a personification occurs. In this line, the lyricist gives an abstract object (heaven) the ability to perform an action.

\section{Imagery analysis}

He's so tall and handsome as hell (line5; Visual Imagery)

In this phrase, the listener invited to imagine the look of lyricist's lover. It is so clear that the word is the imagery which related to visual seeing.

\section{Bad Blood}

\section{Figurative language analysis}

Salt in the wound like you're laughing right at me (line 16; $\quad$ Metonymy)

The sentence above is categorized as metonymy. In that sentence the author used the proverb "salt in the wound" to describes or to replace the original term "pain”. In the context, her lover broke her hearth. The feeling when he laughs at her, it's just like "salt in the wound" and give her pain.

\section{Imagery analysis}

Did you have to ruin what was shiny? Now it's all rusted (line 11-12;Visual Imagery)

The image of visual imagery which is showed in the lyric describes that the lyricist gives the listener some images and situations in their relationship. It was a fine relationship and now it is over.

\section{How You Get the Girl}

\section{Figurative language analysis}

I would wait forever and ever. Broke your heart, I'll put it back together (Line 1011; Hyperbole) 
From the lyric above, the lyricist exaggerating because it is not possible for someone waiting forever and to put a broken heart back together. She interprets it by saying that her boyfriend will make their relationship better than before.

\section{Imagery analysis}

And you were too afraid to tell her what you want (line 5; Organic Imagery)

In this lyric, the listener is given an imagery of internal sensation or organic imagery to express the lyricist's fear in expressing his feeling to his lover.

\section{This Love}

\section{Figurative language analysis}

Clear blue water, high tide came and brought you in (line 1; Personification)

The lyricist personifies the high tide by giving it activity which makes it seem alive. High tide only happens in sea. It is not able to bring people. He uses it to describe the beginning of his relationship which is started well.

\section{Imagery analysis}

Clear blue water, high tide came and brought you in (line 1; Visual Imagery)

Through that word, the lyricist describes the picture of his happiness in the beginning of his relationship which is started well.

\section{Know Places}

\section{Figurative language analysis}

Love's a fragile little flame, it could burn out (line 7; Simile)

The lyricist compares love with flame that could burn out. This line describes that love is not eternal. It easy come and easy go.

\section{Imagery analysis}

It's a scene and we're out here in plain sight (line 2; Visual Imagery) 
Through that word, the listener invited to imagine about the lyricist's love story. This phrase describes that people always talk about their relationship.

\section{Clean}

\section{Figurative language analysis}

You're still all over me like a wine-stained dress (line 4; Simile)

In this lyric, the lyricist uses simile to compare his lover with wine-stained dress. This explains how her memory still in his mind and he could not forget it.

\section{Imagery analysis}

When the flowers that we'd grown together died of thirst (line 2; Visual Imagery)

The listener is given a picture of their relationship which is end badly.

\section{DISCUSSION}

After analyzing the figurative languages and imagery in Song Lyrics by Taylor swift's “1989” album, the researcher concludes:

1. The song lyrics in Taylor Swift's “1989” album consist of eight kinds of figurative language and 42 lyrics that have figurative language. From 42 lyrics, there are 16 items of personification, 5 items of metaphor, 7 items of hyperbole, 6 items of simile, 4 items of oxymoron, 1 item of allusion, 2 items of litotes and 1 item of metonymy.

2. The dominant of figurative language used in the song lyrics is personification and the least are allusion and metonymy.

3. The song lyrics in Taylor Swift's “1989” album consist of 62 lyrics that have imagery. There are 30 items of visual imagery, 6 items of auditory imagery, 10 items of organic imagery, 14 items of kinesthetic imagery, 1 item of tactile imagery and 1 item of olfactory imagery.

4. The dominant of imagery used in the song lyrics of Taylor Swift's 1989” album is visual imagery and the least imagery are tactile and olfactory imagery.

From the analysis, it can be concluded that figurative language and imagery have important roles in this album. They able to beautify the song and also help the listener to 
imagine the story and character based on the illustration that the lyricist has already given in the songs.

The researcher suggests those who are interested in studying about lyrics analysis, they can use many approaches such as figurative language and imagery in comprehending the context and message of their paper. The researcher hopes that this research can give a positive contribution for the readers and help the readers to have a better understanding about the meaning of songs lyrics.

\section{REFERENCES}

Abrams, M. H. (1999). A glosary of literary term seventh edition. Retrieved from: http://www.ohio.edu/people/hartleyg/ref/abrams_mh.pdf.

Arikunto. (2006). Dasar-dasar evaluasi pendidikan. Jakarta: Bumi Aksara.

Arp, Thomas R. and Greg Johnson. (2011). Perrine's sound and sense: An introduction to poetry. $13^{\text {th }}$ Ed.USA: Wadsworth Cengage Learning.

Creswell, John W. (2009). Research design: Qualitative, quantitative and mixed method approaches third edition. USA: Sage Publication.

Dudrah, Rajinder and Jigna Desai. (2008). The Bollywood Reader. Retrieved from: https://books.google.co.id/booksid=4Wz4AAAAQBAJ\&pg.

Grover, Julie. (1994). English literature. UK: Longman Group Uk Limited.

Klarer, Mario. (1999). An Introduction to Literary Studies. Retrieved from http:// perpus. stkipkusumanegara.ac.id/ file_digital /A\%20I ntroduction\%20to \%20Literary\%20Studies.pdf

Mezo, Richard E. (1999). " Fire I' the blood”: A Handbook of Figurative Language. Retrieved from: http://www.bookpump.com/upb/pdf- b/1128347b.pdf.

Semi, Atar M. (2012). Metode Penelitian Sastra. Bandung: Angkasa. 